\title{
Kategoria poczucia bezpieczeństwa w świetle wybranych teorii socjologicznych
}

\author{
https://doi.org/10.19195/2083-7763.10.4
}

\section{Abstrakt}

Artykuł zawiera rozważania dotyczące teoretycznego znaczenia kategorii bezpieczeństwa i poczucia bezpieczeństwa na gruncie socjologii. Pojęcia te są wykorzystywane w teoriach dotyczących różnych poziomów organizacji rzeczywistości społecznej. Krótko zostały omówione przykłady takich zastosowań: a) w implikacjach koncepcji „społeczeństwa ryzyka” U. Becka; b) jako kategoria łącząca działania jednostkowe i własności systemu społecznego w koncepcji M. Marody oraz c) jako pojęcia przydatne do charakterystyki pewnych aspektów porządku interakcyjnego w ujęciu E. Goffmana.

Słowa kluczowe: poczucie bezpieczeństwa, porządek interakcyjny, wytwarzanie normalności, Umwelt

Najogólniejszym tłem przedstawionych w tekście analiz jest pytanie o użyteczny sposób ujęcia kategorii poczucia bezpieczeństwa z perspektywy socjologicznej. Jak się wydaje, kategoria ta dość często jest wykorzystywana w badaniach empirycznych, których celem jest pomiar „poczucia bezpieczeństwa” przedstawicieli jakiejś zbiorowości terytorialnej (miasta, gminy, powiatu itp.). Rezultatem takich przedsięwzięć badawczych są rozkłady opinii respondentów dotyczące częstotliwości występowania różnego rodzaju zagrożeń porządku publicznego w najbliższym otoczeniu, skala odczuwanych obaw przed ich wystąpieniem, rozkłady ocen funkcjonowania różnych służb (na przykład policji) itp. Mierzone są czasem podstawowe charakterystyki społeczno-demograficzne respondentów lub zmienne charakteryzujące zbiorowości terytorialne, co umożliwia analizy korelacyjne. Badania tego rodzaju bywają wykorzystywane w celach praktycznych, mogą 
służyć ewaluacji skuteczności działań na rzecz zapewnienia poczucia bezpieczeństwa jakiejś społeczności, ale jak się wydaje, rzadko związane są z bardziej teoretycznym poziomem analizy. Ich „socjologiczny” charakter wynika chyba raczej $\mathrm{z}$ tego, że wykorzystują metody sondażowe wiązane w potocznym odbiorze z pracą typowego socjologa.

Jednocześnie można znaleźć $\mathrm{w}$ literaturze socjologicznej próby przypisania kategorii bezpieczeństwa (lub poczucia bezpieczeństwa) istotnej roli teoretycznej. W dalszej części tekstu zostaną omówione trzy przykłady takich zastosowań zróżnicowane ze względu na poziom organizacji życia społecznego, do którego się odnoszą: od rozważań dotyczących przemian rzeczywistości społecznej jako globalnego systemu poprzez analizy związków pomiędzy funkcjonowaniem systemu społecznego a działaniami jednostek po rozważania, które dotyczą poziomu bezpośrednich, osobistych interakcji między ludźmi.

W omówieniu tym nie chodzi o kompletny czy nawet reprezentatywny przegląd istniejących teorii, nie sugeruję też, że przywołane teorie są ważniejsze od innych. Celem jest raczej ilustracja tezy, że kategoria bezpieczeństwa może stanowić element socjologicznych teorii z pożytkiem stosowanych do analizy zjawisk z różnych poziomów rzeczywistości społecznej.

Jeśli przyjąć diagnozę, że współczesne społeczeństwo jest „społeczeństwem ryzyka"1, to jedną z konsekwencji takiego rozpoznania jest waga szeroko rozumianego bezpieczeństwa. Zwłaszcza że nowe „stadium nowoczesności” związane jest silnie $\mathrm{z}$ ujawnieniem się nieprzewidywalnych zagrożeń „W zachodnim środowisku zinstytucjonalizowanego bezpieczeństwa”, co stawia „pod znakiem zapytania funkcjonowanie instytucji zapewniających bezpieczeństwo i kontrolę pierwszej, industrialnej, zorganizowanej w państwa narodowe współczesności”2. Zagrożenia wytwarzane przez samo społeczeństwo przemysłowe rodzi potrzebę (by posłużyć się kolejnym cytatem) „ponownego określenia standardów (odpowiedzialności, bezpieczeństwa, monitorowania, ograniczania szkód i dystrybucji ich konsekwencji) określonych wcześniej bez uwzględniania potencjalnych zagrożeń"3.

W rozważaniach teoretycznych z tego poziomu kategoria bezpieczeństwa, choć istotna i wzbogacająca rozumienie natury współczesności, nie jest przedmiotem bezpośrednich i systematycznych analiz ani nie służy do wskazania określonego procesu lub mechanizmu wykorzystywanego bezpośrednio w wyjaśnianiu ludzkich zachowań.

Przykładu socjologicznej koncepcji, w której pojęcia bezpieczeństwa i poczucia bezpieczeństwa zostały efektywnie wykorzystane do budowy modelu eks-

${ }^{1}$ U. Beck, Społeczeństwo ryzyka, przeł. S. Cieśla, Warszawa 2004.

2 Ibidem, s. 347.

${ }^{3}$ U. Beck, A. Giddens, S. Lasch, Modernizacja refleksyjna. Polityka, tradycja i estetyka w porząku społecznym nowoczesności, przeł. J. Konieczny, Warszawa 2009, s. 18. 
planacyjnego, mogą dostarczyć rozważania Mirosławy Marody stanowiące ogólną ramę teoretyczną analiz zawartych w pracy zbiorowej Co nam, zostało $z$ tych lat... Społeczeństwo polskie u progu zmiany systemowej (1991) poświęconej załamaniu się systemu „realnego socjalizmu” w Polsce lat osiemdziesiątych XX wieku. Przydatność wspomnianych pojęć - a w szczególności pojęcia „bezpieczeństwa społecznego" - wiąże się, zdaniem autorki, z ich konkretnością wystarczającą do oddania specyfiki jednostkowych działań oraz jednocześnie z takim poziomem ogólności, który umożliwia ich odniesienie do relacji łączących własności systemu społecznego i jednostkowe działania.

Marody stawia tezę, że pod koniec wieku XX na skutek złożonego układu czynników doszło do zmiany w reakcji ludzi na doświadczane przez nich zagrożenia - nastąpiło „przeniesienie uwagi z obrony przed lękiem na poszukiwanie środków podnoszących poczucie bezpieczeństwa”. I tym samym „nie lęk, lecz bezpieczeństwo staje się centralnym problemem naszych czasów"4.

Samo pojęcie „poczucia bezpieczeństwa” badaczka określa negatywnie poprzez wskazanie na brak zagrożenia. $Z$ kolei poczucie zagrożenia ujmuje jako powiązane z zablokowaniem możliwości realizacji potrzeb niezbędnych $\mathrm{w}$ funkcjonowaniu jednostki. Można, ogólnie rzecz biorąc, wyróżnić trzy podstawowe klasy takich potrzeb: dążenia do zapewnienia fizycznego trwania (poziom biologiczny), dążenia do ustalenia i potwierdzenia własnej tożsamości (poziom psychologiczny) i dążenia do zbudowania poczucia sensu życia (poziom życia świadomego jednostki).

Dążenia te mogą być zrealizowane w określonej przestrzeni społecznej i formy ich przejawiania się są społecznie determinowane. System społeczny rozumiany jako zasady organizacji społeczeństwa, całokształt instytucji społecznych, zasady postępowania wyznacza określone zbiory dostępnych jednostkom „technik życia”. Społecznie tworzone są także wzory kulturowe oraz standardy cywilizacyjne, które dostarczają podstawy formułowania celów jednostkom oraz układów odniesienia do oceny poziomu realizacji wspomnianych dążeń. Ze względu na ten splot „technicznych” (jak określa to autorka) i „normatywnych” aspektów uspołecznienia źródłem zagrożeń nie jest niedostępność jakichkolwiek technik realizacji podstawowych dążeń, ale „zablokowanie takich technik, które stwarzają możliwości ich realizacji w społecznie pożądanej formie" 5 .

Typ porządku społecznego (określony system instytucji, norm, systemów wiedzy potocznej itp.) mediuje między ogólnymi, abstrakcyjnie wyżej ujętymi dążeniami człowieka a konkretnymi działaniami, które podejmują jednostki. Determinuje formy tych działań, ograniczając spectrum możliwych do skutecznego wykorzystania technik życia, oraz definiuje społeczne zasoby będące

${ }^{4}$ Co nam, zostało z tych lat... Społeczeństwo polskie u progu zmiany systemowej, red. M. Marody, Warszawa 1991, s. 8.

${ }^{5}$ Ibidem, s. 11.

Forum Socjologiczne 10, 2020

(C) for this edition by CNS 
w dyspozycji jednostek mogące zostać „skapitalizowane” jako środki do osiągania celów. Ponieważ cechą społeczeństw nowoczesnych jest odejście od bezpośrednich, osobistych regulacji działan ludzkich i powstanie abstrakcyjnych, formalnych struktur (pieniądz, system prawny itp.) oraz sieci instytucji, które regulują i koordynują działania jednostek, rośnie uspołecznienie społeczeństwa, to znaczy „stopień, w jakim funkcjonowanie jednostek uzależnione jest od funkcjonowania całości systemu społecznego". Zdaniem cytowanej autorki oznacza to modyfikację pojęcia bezpieczeństwa, które z problemu jednostkowego staje się problemem społecznym. Konsekwencją tego stanu rzeczy, gdy efektywność działań jednostki zależy przede wszystkim od sprawnego przebiegu interakcji $\mathrm{z}$ innymi osobami występującymi $\mathrm{w}$ instytucjonalnie zdefiniowanych rolach społecznych oraz uznawania wzajemnych roszczeń jednostek jest, że ,jednym z czynników decydujących o efektywności tych działań staje się podzielanie przez ludzi sensów wszystkiego tego, co tworzy porządek społeczny"6.

Poczucie bezpieczeństwa oznacza w praktyce stan „swoistego zakorzenienia jednostek w systemie społecznym” umożliwiający jednostkom „oswajanie rzeczywistości”, postrzeganie jej w kategoriach „swojskości”, „normalności”, „sensowności” itp. Jednostka wie, jak zachowają się inni i jak ona sama ma się zachować w różnych sytuacjach życia społecznego.

Ubocznym efektem funkcjonowania systemu społecznego, choć mającym dla niego duże znaczenie, jest podzielane przez jednostki poczucie bezpieczeństwa społecznego. Marody określa je jako pewność, że instytucje składające się na system społeczny będą funkcjonować zgodnie z przypisanymi im społecznie sensami. Sprawnie funkcjonujący system instytucjonalny umożliwia pojawienie się w życiu jednostek sfer bezpieczeństwa, ogranicza zakres nieprzewidywalności i przypadkowości towarzyszący ich działaniom. Ujmowane z innej strony poczucie bezpieczeństwa społecznego ,jest równoznaczne z poczuciem zalegitymizowanych roszczeń, jakie jednostka może wysuwać pod adresem systemu społecznego i poszczególnych jego instytucji”"

Jednak każdy porządek społeczny, regulując („pacyfikując” — jak pisze autorka) określone obszary rzeczywistości społecznej, generuje nowe, specyficzne problemy stające się źródłem zagrożeń bezpieczeństwa jednostek. W odpowiedzi na nie jednostki wypróbowują nowe sposoby działania, z których niektóre mogą $\mathrm{z}$ czasem ulec instytucjonalizacji i zostać zintegrowane $\mathrm{z}$ systemem.

Opisana aparatura pojęciowa służy badaczce do nakreślenia dynamiki narastania $\mathrm{w}$ wyniku załamania się porządku społecznego poczucia zagrożenia bezpieczeństwa społecznego w systemie „realnego socjalizmu” w Polsce. Obraz rozpadu systemu abstrakcyjnych regulacji oraz instytucji mediujących między poziomem podstawowych dążeń jednostek a konkretnymi działaniami w kontekście

\footnotetext{
${ }^{6}$ Ibidem, s. 16.

${ }^{7}$ Ibidem, s. 19.
} 
uwewnętrznionych przez jednostki w postaci specyficznego typu racjonalności fundamentalnych standardów charakterystycznych dla społeczeństwa nowoczesnego nie będzie przedmiotem omówienia w niniejszym opracowaniu ${ }^{8}$. Koncepcja Mirosławy Marody została przytoczona tu jako przykład możliwości, jakie otwiera dla socjologów wykorzystanie kategorii bezpieczeństwa w roli pojęcia wiążącego poziom jednostkowych działań z funkcjonowaniem systemu społecznego.

Socjologiczne ujęcie problematyki bezpieczeństwa możliwe jest nie tylko w kontekście analiz „całej rzeczywistości społecznej” i analiz relacji między działaniami jednostkowymi a funkcjonowaniem systemu społecznego ${ }^{9}$. W dalszej części tekstu chciałbym skupić się na omówieniu wybranych rozważań dotyczących szczególnego wymiaru rzeczywistości społecznej, który Erving Goffman określił mianem "porządku interakcyjnego" ${ }^{10}$. Obejmuje on sferę kontaktów twarzą-w-twarz między ludźmi. Zdaniem wspomnianego badacza „porządek interakcyjny tworzy odrębną sferę rzeczywistości, ujawniającą własną specyficzną dynamikę" ${ }^{11}$, której nie można w prosty sposób sprowadzić do poziomu ani mikro-, ani makrozjawisk społecznych. Nie znaczy jednak, że dotyczy on kwestii mało istotnych dla życia społecznego. Jak zapewnia Jonathan H. Turner, omawiając twórczość Goffmana, „znaczna część tego, co nadaje światu społecznemu sens »bycia realnym « powstaje z praktyk jednostek, tego jak traktują się nawzajem $\mathrm{w}$ rozmaitych sytuacjach" 12 .

W dalszej części tekstu skupię się na przybliżeniu rozważań Goffmana z eseju Pozory normalności opublikowanego w pracy Relacje w przestrzeni publicznej i ocenie ich przydatności do badania problematyki poczucia bezpieczeństwa. Z punktu widzenia przyjętego $\mathrm{w}$ niniejszym tekście można zinterpretować omawiane rozważania socjologa jako poświęcone badaniu związków między doświadczeniem zaniepokojenia a poczuciem bezpieczeństwa w sytuacjach kreowanych przez bezpośrednie kontakty między ludźmi.

${ }^{8}$ Tym bardziej że nie została $\mathrm{w}$ omawianej pracy rozwinięta kompletna teoria dynamiki społecznej. Nie jest jasne na przykład, co i w jakim stopniu jest motorem opisywanych zmian: czy „sprzeczności lub/i ograniczenia systemu”, czy może zgodnie z „mertonowskim” schematem myślenia „system wyznacza cele jednostkom i blokuje dostęp do środków”, czy może motoru tego należy szukać w imperatywnym charakterze jednostkowych potrzeb uruchamiających ich działania, lub/i w jakiejś innowacyjności jednostek poszukujących nowych „technik życia”. Nawiasem mówiąc, intrygujące jest, że w przypadku omawianej koncepcji ludzkie dążenie do osiągnięcia bezpieczeństwa posłużyło do wyjaśnienia wysiłków przejścia od zamkniętego systemu społecznego do bardziej otwartego. W odmiennym kontekście pojęciowym dążenie takie posłużyło do wyjaśnienia przejścia z otwartego systemu do autorytaryzmu — jak w klasycznej pracy Ericha Fromma Ucieczka od wolności (1993).

${ }^{9}$ Podejście takie wydaje mi się szczególnie owocne teoretycznie na gruncie socjologii.

10 Por. E. Goffman, Porządek interakcyjny, przeł. A. Manterys, [w:] Wspótczesne teorie socjologiczne, red. A. Jasińska-Kania et al., t. 1, Warszawa 2006.

${ }^{11}$ J.H. Turner, Struktura teorii socjologicznej, przeł. G. Woroniecka et al., red. A. Manterys, G. Woroniecka, Warszawa, 2004, s. 456.

12 Ibidem, s. 457.

Forum Socjologiczne 10, 2020

(C) for this edition by CNS 
Jak pisze Goffman, ludzie (ale też zwierzęta) funkcjonują w dwóch podstawowych trybach aktywności: pierwszy to spokojne „zajmowanie się swoimi sprawami”, drugi zaś to zaalarmowanie, mobilizacja i gotowość do ataku lub ucieczki. Pierwszy z trybów aktywności jednostka przejawia, gdy otoczenie „nie zwiastuje niczego niepokojącego". Okoliczności takie są uznawane za „,normalne”, „naturalne”. Ostrożność jest wtedy „zaangażowaniem pobocznym” w relacji do zaabsorbowania bieżącymi sprawami.

Przedmiotem analiz Goffmana jest kategoria „normalności”. Jedną z najistotniejszych wynikających z nich konkluzji jest, że „normalność” musi w istocie być starannie wypracowywana i podtrzymywana przez ludzi w toku codziennych interakcji. Jest zatem „produktem” określonych procesów i mechanizmów, które niewątpliwie zasługują na uwagę. Zgodnie z przyjętą interpretacją mechanizmy te i procesy są tożsame $\mathrm{z}$ wytwarzaniem pewnych przynajmniej aspektów „poczucia bezpieczeństwa".

Goffman zauważa, że w odniesieniu do okoliczności „normalnych” zazwyczaj oprócz oczekiwań typowości statystycznej ludzie formułują także oczekiwania normatywne. Po pierwsze, ,jednostka nie tylko spodziewa się spokoju, lecz także czuje, że ma do niego moralne prawo"13. Po drugie, zazwyczaj okoliczności normalne to zarazem okoliczności stosowne. Odnosi się to w szczególności do przypadku, gdy takie okoliczności są konstytuowane zarówno przez zachowania samej jednostki, jak i innych ludzi. Takie dopasowanie „typowości” i „stosowności" jest wynikiem adaptacyjnego procesu społecznego i nieustannie jest zagrożone ryzykiem pojawienia się rozbieżności.

Niestosowne zachowania bywają sygnałem alarmowym dla agentów kontroli społecznej. Także, jak zauważa Goffman, ludzie, dostrzegając, że ktoś przebywający w ich otoczeniu zachowuje się niestosownie lub w jakiś inny sposób „nie pasuje” do otoczenia, mogą dojść do wniosku, że choć „dziwactwo” takie samo w sobie nie jest zagrażające, to „ludzie dziwaczni pod jednym względem mogą być dziwaczni także pod innymi względami, a to może okazać się niebezpieczne"14. Sugeruje, że codzienne rytuały, na przykład wymiana pozdrowień czy uprzejma nieuwaga, mogą być „systemem wczesnego ostrzegania”. Zakłócenie czy ich brak może wywoływać niepokój.

Jednostki mogą poprzez elementy swojego zachowania sygnalizować innym zagrożenie $^{15}$, ale także wysyłać komunikat „wszystko w porządku”.

Istotnym czynnikiem określającym percepcję przez jednostkę tego, co w sytuacji jest dla niej niepokojące, stanowi jej indywidualne doświadczenie i nabyte kompetencje. Warto podkreślić, że większość nawet najprostszych umiejętności

${ }^{13}$ E. Goffman, Relacje w przestrzeni publicznej, przeł. O. Siara, Warszawa, 2011, s. 291.

${ }^{14}$ Ibidem, s. 299.

${ }^{15} \mathrm{Na}$ przykład zdarzenie, które może się okazać źródłem niepokoju, wymaga poświęcenia mu większej uwagi, zatem przyglądanie się czemuś dłużej, niż wymaga typowa lustracja otoczenia, przyciągnie uwagę innych współobecnych. Ibidem, s. 305.

Forum Socjologiczne 10, 2020

(C) for this edition by CNS 
jest zazwyczaj produktem złożonego procesu ich nabywania ${ }^{16} \mathrm{i}$ nie brakuje w życiu okoliczności, w których kompetencje takie przestają się sprawdzać (stres, choroba, nowa praca i inne zmiany w organizmie i otoczeniu). Jednostki także uczą się unikać sytuacji, które wymagałyby od nich umiejętności zbyt trudnych lub niemożliwych wręcz do opanowania. Co więcej, istnieją zinstytucjonalizowane mechanizmy kontroli niebezpieczeństw, często wręcz ucieleśnione na przykład w praktykach budowlanych, produkcyjnych lub transportowych, które powodują, że szczególne środki ostrożności nie są potrzebne. „Fakt, że większość domów w Stanach Zjednoczonych ma wystarczający zasób gazu i elektryczności, aby dokonać egzekucji, zazwyczaj nie spędza mieszkańcom snu z powiek" — pisze Goffman ${ }^{17}$.

$\mathrm{Na}$ określenie pola doświadczeń jednostki mających znaczenie dla analizowanej problematyki zaniepokojenia i „normalności” omawiany badacz wprowadza kategorię Umweltu o fenomenologicznych konotacjach, ale zaczerpniętą z prac etologów. Umweltem nazywa

obszar wokół jednostki, w granicach którego mieszczą się potencjalne źródła niepokoju. [...] Ponieważ źródła niepokoju zazwyczaj dostarczają powodów do zaniepokojenia, Umwelt jednostek można zdefiniować jako otaczający ją obszar, w którym mogą pojawić się powody do niepokoju ${ }^{18}$.

Zazwyczaj źródła takie usytuowane są w bezpośredniej bliskości fizycznej jednostki, a jej obawy przede wszystkim dotyczą własnego ciała, które w rozmaity sposób może być narażone na zagrożenia i ataki. Istnieją oczywiście w ludzkich Umwelt ach „okna”, które informują za pośrednictwem rozmaitych „sztucznych receptorów" (telefon, inne media itp.) o odległych przestrzennie wydarzeniach, ale $\mathrm{w}$ wyjątkowych tylko wypadkach informacje takie wymagają natychmiastowego działania. Umwelt jest „egocentryczną przestrzenią wokół interesanta [...], czymś w rodzaju ruchomego frontu istotności” ${ }^{19}$ przemieszczającego się wraz $\mathrm{z}$ jednostką.

Z punktu widzenia socjologii interesująca jest sytuacja, gdy źródłem niepokoju w Umwelcie jednostki są inni ludzie. Jak zauważa Goffman, takie osoby, które kogoś mogą zaniepokoić swoimi działaniami, zazwyczaj biorą to pod uwagę. Mogą mianowicie uważać, że choć nie tworzą zagrożenia, to w ich interesie należy przekonanie innych, że jest odwrotnie. Częściej jednak uważają, że niepokój innych byłby nieuzasadniony i woleliby go uniknąć. W innych okolicznościach zainteresowani są zatajeniem rzeczywistego źródła niepokoju: „jeśli są drapieżnikami,

16 „Chodzenie, przechodzenie przez ulicę, mówienie płynnymi zdaniami, dodawanie — wszystkie te rutynowe umiejętności, z których korzystamy automatycznie i kompetentnie, nabyliśmy w procesie akwizycji, a jego początki były trudne”. Ibidem, s. 307.

${ }^{17}$ Ibidem, s. 309.

18 Ibidem, s. 311.

19 Ibidem, s. 315 
zapewne pragną podejść na tyle blisko, by móc rzucić się na ofiarę; jeśli są ofiarami prawdopodobnie nie chcą zwracać na siebie uwagi drapieżnika” 20 .

W każdym jednak z wymienionych wypadków osoby takie muszą zaangażować się w stwarzanie pozorów normalności, przy czym punktem jej odniesienia nie jest Umwelt własny, lecz partnera, przeciwnika lub ofiary. Goffman ilustruje sposoby wytwarzania pozorów normalności wieloma barwnymi przykładami. Szczególne znaczenie dla uchwycenia mechanizmów takiego fabrykowania „,normalności" mają różne formy działalności przestępczej, których autorzy dla realizacji swoich zamiarów muszą z konieczności stać się w „fenomenologami, wnikliwymi badaczami codzienności - rzecz jasna nie własnej, tylko tego, co dany podmiot uważa za codzienność" 21 . Ta działalność rzuca światło na struktury i kompetencje konieczne do stwarzania pozorów normalności w bardziej niewinnych i koniecznych dla harmonijnego życia społecznego sytuacjach.

Szczególną odmianą technik wytwarzania normalności jest dostarczanie zaniepokojonemu podmiotowi uspokajających informacji przez jednostki, które taki niepokój wywołały. Złożenie wyjaśnień wzmacniane czasami innymi formami tak zwanej pracy naprawczej przedstawia sytuację w taki sposób, aby nie budziła niepokoju. Zaniepokojone jednostki z reguły powstrzymują się z natychmiastową reakcją w obliczu niepokojących działań innych, dając im szansę złożenia wyjaśnień. „Dobre” wyjaśnienia to wyjaśnienia skuteczne i niekoniecznie prawdziwe. Analiza tego typu interakcji prowadzi Goffmana do konstatacji: „niezależnie jak dziwaczne i niebezpieczne było niepokojące zdarzenie, zawsze można skutecznie je wyjaśnić, czyli złożyć prawdziwe lub fałszywe wyjaśnienie, które uśmierzy podejrzenia” 22 . W tym sensie „normalne okoliczności” mają charakter otwarty i są podatne na szczególnego rodzaju negocjacje.

Warto jeszcze raz podkreślić, że w świetle omawianej koncepcji podobne co do struktury działania będą podejmować zarówno „drapieżnicy” pragnący ukryć przed podmiotem zagrożenie, jak i „ofiary” starające się zataić swoją słabość.

Istnieją także dość częste okoliczności, $\mathrm{w}$ których podmiot dostrzegający w swoim Umwelcie coś niepokojącego, dochodzi do wniosku, że w jego interesie jest ukryć swój niepokój i „zachowywać się naturalnie”, podejmując paradoksalne zadanie odgrywania (czy symulowania) samego siebie. Takie samonaśladownictwo może pojawić się też, gdy podmiot ma interes w okłamywaniu innych osób, zazwyczaj tych, z którymi pozostaje w bliskich związkach (ukrywanie romansu przed współmałżonkiem), w sytuacjach gdy zastawia na kogoś pułapkę i wreszcie w wyjątkowych przypadkach robi to pod przymusem ze strony innych wykorzystujących go instrumentalnie do celów na przykład przestępstwa.

${ }^{20}$ Ibidem, s. 317.
${ }^{21}$ Ibidem, s. 320.
${ }^{22}$ Ibidem, s. 328.

Forum Socjologiczne 10, 2020

(C) for this edition by CNS 
Odgrywanie normalności ma duże znaczenie dla pracy nad podtrzymywaniem akceptowalnej wizji samego siebie — jednostki są głęboko zainteresowane robieniem takiego wrażenia, aby inni nie zwracali na nich uwagi. W wielu okolicznościach podmiot, jak i inni „mają podobny cel - chcą wydawać się normalni - choć być może z innych powodów"23.

W drugiej części eseju Goffman podejmuje próbę określenia struktury Umweltu i zbadania założeń, jakie jednostki przyjmują wobec jego elementów. Każdy z wyróżnionych elementów zawiera specyficzne źródła potencjalnego zagrożenia. Przy ich rozpatrywaniu cytowany badacz skupia się przede wszystkim na zagrożeniach związanych z wrażliwością ciała i zakłóceniami „dystansu krytycznego".

Elementy składające się na Umwelt to: 1. wyposażona rama, 2. granice przyczajenia, 3. punkty dostępu, 4. sieci społeczne. Krótko zostaną one omówione.

1. Wyposażona rama - stanowi rodzaj fizycznego ograniczenia (mury, szpaler budynków itp.) pewnej przestrzeni ustanawiającego podział na „wnętrze” i „zewnętrze". Zakłada się, że rama jest barierą dla potencjalnych powodów niepokoju, a jej wnętrze ma własności uspokajające. Zakłada się także, że przedmioty znajdujące się we wnętrzu nie są zagrożeniem dla osób mających określony zakres kompetencji. Rama sama w sobie jest nieszkodliwa. Założenie to oczywiście w określonych sytuacjach może być nieprawdziwe. Rama ma też niepokojącą właściwość - fizyczne bariery odcinające od zewnętrznych niebezpieczeństw mogą w szczególnych okolicznościach uwięzić jednostkę razem ze źródłem zagrożenia, które przeniknie do wnętrza.

2. Granice przyczajenia. $Z$ właściwości organów percepcji wynika, że niezależnie od położenia ciała istnieją „martwe punkty” znajdujące się poza zasięgiem obserwacji, na przykład obszar „za plecami” jednostki. Istnieją także przeszkody zasłaniające to, co znajduje się poza nimi. „Martwym punktem” może być niewielka przestrzeń między stłoczonymi na przykład w metrze ludźmi. „Martwe punkty” na ulicach generuje zapadnięcie zmroku. „Martwe punkty” pozostają poza zasięgiem bezpośredniej obserwacji, ale są wystarczająco blisko, aby mogło tam się ukrywać źródło zagrożenia. Istota obszaru przyczajenia wiąże się z brakiem fizycznych i społecznych barier między nim a jednostką. Granice przyczajenia mogą być łatwo przekroczone.

3. Punkty dostępu. Każdy Umwelt je zawiera, nawet gdy jest częściowo fizycznie odizolowany od otoczenia fizycznymi granicami. W każdym istnieją drzwi i wejścia w sensie dosłownym i metaforycznym. Jednostka jest dostępna w pewnych okolicznościach dla nieznajomych, nawet na ulicy można uzyskać do niej dostęp konwersacyjny, wykorzystując konwencjonalne znaki wskazujące na prośbę o wysłuchanie. Goffman zwraca uwagę, że punkty dostępu są chronione za pomocą rozmaitych konwencji przed użytkowaniem, które byłoby uznane za niewłaściwe.

\footnotetext{
${ }^{23}$ Ibidem, s. 343.
} 
Ale konwencje takie mogą być oczywiście złamane i punkty dostępu mogą przeobrazić się w źródła niepokoju.

4. Sieci społeczne - inni nader łatwo mogą być przedmiotem zaniepokojenia. Cytowany autor podkreśla, że dość dobrze znane są zarówno uczestnikom interakcji, jak i badaczom, niebezpieczeństwa, mogące zagrażać jednostce ze strony innych osób, w których towarzystwie się znajduje. Z tego względu Goffman skupia się jedynie na podkreśleniu roli „społecznych” informacji w tej kwestii. Informacja nazywana jest społeczną, jeśli dotyczy informatora i jest przekazywana ludziom $\mathrm{w}$ jego obecności ${ }^{24}$. W szczególności informacje te dotyczą społecznej i osobistej tożsamości informatora, jego intencji i planów działania oraz jego społecznych związków z pozostałymi osobami.

Jednostka wchodząca w interakcję zakłada, że uzyska dostęp do takich informacji i pozwoli to ocenić, czy zbiorowość („formacja”, grupa) powinna budzić zaniepokojenie. Jednocześnie oczekuje, iż uzyska informacje pozwalające jej samej zachowywać się w sposób niewzbudzający zaniepokojenia innych. Informacje takie są niezbędne, aby jednostka mogła się poczuć w sytuacji swobodnie. Zazwyczaj $\mathrm{w}$ toku interakcji wspomniane oczekiwania są spełnione, jednak „społeczne informacje" mogą być łatwo zmanipulowane.

W ostatniej, trzeciej części swojego eseju Goffman precyzuje kolejne charakterystyki Umweltu. Tym razem punktem odniesienia jest działająca jednostka wyposażona w określone intencje, plany lub zadania, cele itp. W tym kontekście podstawowe znaczenie ma dokonywana przez działającego klasyfikacja wszelkich zdarzeń w jego otoczeniu na zaplanowane (wywołane celowo przez niego samego lub innych) i niezaplanowane. Jest to podział Umweltu na „przedsięwzięcie i scenerię, na elementy zorientowane na Ja i elementy przypadkowe". Cały obszar Umweltu niewiążący się z jej bezpośrednimi planami jednostka może traktować jako oczywistość (coś, na co można bezpiecznie nie zwracać uwagi). Drugą konsekwencją tego założenia jest przekonanie, że bieżące plany jednostki nie interesują różnego rodzaju „agencji” i podmiotów odpowiedzialnych za to, co się wokół dzieje. Na skutek tego może ona uznać za „czysty przypadek”, „zbieg okoliczności” rozmaite zdarzenia, które nie tylko byłyby w wysokim stopniu niepokojące, lecz także mogą mieć brzemienne skutki dla jej życia („pech”, „szczęśliwy traf”).

Te założenia tłumaczą między innymi dlaczego, jeżeli nie wszystko dzieje się tak jak jednostka oczekiwała, nie musi to budzić jej niepokoju. Niemniej do swobodnego działania konieczne jest, aby jednostka była w stanie przeprowadzić w każdej sytuacji podział między tym, co zaplanowane, a tym, co niezaplanowane.

Koncepcja „podstępu” oznacza możliwość manipulowania granicą między niezaplanowanym a zaplanowanym, aranżowania zdarzeń, pozornie przypadkowych, mogących skłonić jednostkę do działań, które okażą się powodem niepokoju. Co więcej, przypadkowe i nieistotne zdarzenia (na przykład przypadkowy

\footnotetext{
${ }^{24}$ Ibidem, s. 372.
} 
kontakt z nieznajomą osobą) mogą być oportunistycznie wykorzystane przez innych do wyrządzenia jej krzywdy (podczas takiego kontaktu zostaną zebrane informacje umożliwiające "drapieżnikom” niecne działania). Goffman opisuje liczne przykłady manipulowania podziałem na zaplanowane i przypadkowe, analizuje rytuały rozwijające się wokół „drugich spotkań” osób nieznajomych normalizujące ich przypadkowość itp.

Jedną z ciekawych konkluzji wynikających z omawianych rozważań jest wykazanie, że w szczególnego rodzaju okolicznościach, ze względu na możliwość istnienia „podstępów”, możliwych manipulacji podziałem na zaplanowane i przypadkowe, ale też z wcześniej rozważanych możliwości wytwarzania pozorów normalności, normalne okoliczności mogą stać się przedmiotem głębokiego zaniepokojenia. Natura ludzkich Umw eltów sprawia, że jesteśmy gotowi w zwyczajnych okolicznościach widzieć dowód spisku.

Koncepcje, których przykładem mogą być zrelacjonowane rozważania Mirosławy Marody, pokazują przydatność kategorii bezpieczeństwa (poczucia bezpieczeństwa) do budowania teoretycznych schematów eksplanacyjnych służących do wyjaśniania ludzkich zachowań i jednocześnie przydatnych do uchwycenia pewnych aspektów dynamiki społecznej. Z kolei analiza świata społecznego taka, jakiej przykładem mogą być rozważania Ervinga Goffmana, pokazuje, jak złożona i krucha jednocześnie może być konstrukcja poczucia bezpieczeństwa publicznego. Jest ono wytwarzane przez wiele interakcyjnych, poznawczych i emocjonalnych procesów. Wyniki analizy struktury Umweltów jednostek pokazują podstawowe lokalizacje źródeł niepokoju i wydaje się, że uzasadniony jest postulat, aby były brane pod uwagę przy konstrukcji narzędzi badawczych służących do pomiaru „poczucia bezpieczeństwa” w konkretnych zbiorowościach. Pozwoliłoby to na precyzyjniejszą ocenę nie tylko źródeł zagrożenia tego poczucia, ale też warunków, od których ono zależy. Wyszlibyśmy wtedy w badaniach empirycznych poza proste konstatacje (przez domniemanie traktowane jako konkluzje badania), że w danej zbiorowości dany odsetek respondentów upatruje w zjawisku X zagrożenia poczucia bezpieczeństwa, a inny odsetek w zjawisku Y.

\section{Bibliografia}

Beck U., Społeczeństwo ryzyka. W drodze do innej nowoczesności, przeł. S. Cieśla, Warszawa 2004.

Beck U., Giddens A., Lash S., Modernizacja refleksyjna. Polityka, tradycja i estetyka $w$ porzadku społecznym nowoczesności, przeł. J. Konieczny, Warszawa 2009.

Fromm E., Ucieczka od wolności, przeł. O. i A. Ziemilscy, Warszawa 1993.

Goffman E., Porządek interakcyjny, przeł. A. Manterys, [w:] Współczesne teorie socjologiczne, t. 1, red. A. Jasińska-Kania et al., Warszawa 2006.

Goffman E., Relacje w przestrzeni publicznej, przeł. O. Siara, Warszawa 2011.

Misztal B.A., Normality and Trust in Goffman's Theory of Interaction Order, Sociological Theory" 19, 2001, z. 3.

Marody M., Działania jednostek a system społeczny, [w:] Co nam zostało z tych lat... Społeczeństwo polskie u progu zmiany systemowej, red. M. Marody, Aneks, Londyn 1991. 
Nasar J.L., Fish B., 'Hot spots' of fear and crime: A multi-method investigation, „Journal of Environmental Psychology" 13, 1993, z. 3.

Pleysier S., Local governance of safety and the normalization of behavior, „Crime, Law and Social Change" 64, 2015, nr 4-5.

Turner J.H., Struktura teorii socjologicznej. Wydanie nowe, przeł. G. Woroniecka et al., red. A. Manterys, G. Woroniecka, Warszawa 2004.

Weigert A.J., Terrorism, Identity, and Public Order: A Perspective From Goffman, „Identity” 3, 2003, z. 2.

\section{A sense of safety in the light of selected sociological analysis}

\section{Summary}

The article addresses the theoretical importance of the category of safety and a sense of safety in sociology. These concepts are used in theories referring to different levels of social reality. The paper contains a brief discussion on (a) implications of U. Beck's concept of the 'risk society'; (b) usage of these concepts as a link between individual actions and social system attributes in M. Marody's conception; (c) as constructs useful in characterizing certain aspects of the interaction order by E. Goffman.

Keywords: sense of safety, the interaction order, production of normalcy, Umwelt 